\title{
Effect of whole-body cryotherapy treatments on the functional state of patients with MS (multiple sclerosis) in a Timed 25-Foot Walk Test and Hand Grip Strength Test
}

\section{Wpływ zabiegów krioterapii ogólnoustrojowej na stan funkcjonalny chorych na MS (multiple sclerosis) w ocenie Timed 25-Foot Walk oraz Hand Grip Test}

\author{
Anna Lubkowska ${ }^{\circledR}$, Aleksandra Radecka', Anna Knyszyńska, Joanna Łuczak²,3 \\ 1 Pomorski Uniwersytet Medyczny w Szczecinie, Katedra i Zakład Diagnostyki Funkcjonalnej i Medycyny Fizykalnej, ul. Żołnierska 54, 71-210 Szczecin \\ Pomeranian Medical University in Szczecin, Chair and Department of Functional Diagnostics and Physical Medicine \\ ${ }^{2}$ Wyższa Szkoła Inżynierii i Zdrowia w Warszawie, Wydział Nauk o Zdrowiu, ul. Bitwy Warszawskiej 1920 r. 18, 02-366 Warszawa \\ College of Engineering and Health in Warsaw, Faculty of Health Sciences \\ ${ }^{3}$ Centralny Szpital Kliniczny Ministerstwa Spraw Wewnętrznych i Administracji w Warszawie, Oddział Rehabilitacji Kardiologicznej, ul. Wołoska 137, 02-507 Warszawa \\ Central Clinical Hospital of the Ministry of Internal Affairs and Administration in Warsaw, Department of Cardiological Rehabilitation \\ anna.lubkowska@pum.edu.pl
}

\begin{abstract}
Introduction: Whole-body cryotherapy (WBC) is one of the main elements of comprehensive rehabilitation of patients with multiple sclerosis (MS). It is used both to improve the mental and physical condition of patients.

The study attempts to assess the effect of a series of 20 daily WBC treatments on global walking function and muscle strength in patients with MS.

Materials and methods: The study included 25 patients with diagnosed MS (ICD10-G35), mean age $44.58 \pm 12.15$ years, who after a detailed medical examination were qualified to a series of 20 daily WBC treatments. Treatments lasted 2-3 min at $-110^{\circ} \mathrm{C}$. Before and after the series of WBC treatments, all subjects were tested for global hand grip and thumb strength using a hydraulic dynamometer $(\mathrm{kg})$ for both the right and the left hands, as well as measuring the time needed to walk a distance of 7.6 metres, in accordance with the Timed 25-Foot Walk Test,
\end{abstract}

\section{ABSTRAKT}

Wstęp: Krioterapia ogólnoustrojowa (whole-body cryotherapy - WBC) stanowi jeden z głównych elementów kompleksowej rehabilitacji pacjentów ze stwardnieniem rozsianym (MS). Stosowana jest w celu poprawy stanu psychicznego i fizycznego chorych. W badaniach podjęto próbę oceny wpływu serii 20 codziennych zabiegów WBC na globalną funkcję chodu oraz siłę mięśniową u chorych na MS.

Materiały i metody: Do badania włączono 25 chorych (średnia wieku to $44,58 \pm 12,15$ lat) z rozpoznanym MS (ICD10-G35), którzy po szczegółowym badaniu lekarskim zostali zakwalifikowani do serii 20 codziennych zabiegów WBC. Zabiegi trwały 2-3 min w temperaturze $-110^{\circ} \mathrm{C}$. Przed i po serii zabiegów WBC u wszystkich badanych dokonano pomiaru globalnej siły zacisku ręki oraz kciuka z zastosowaniem dynamometru hydraulicznrgo (kg) po stronie prawej i lewej, a także pomiaru czasu

\section{INTRODUCTION}

Multiple sclerosis (MS) is a chronic progressive demyelinating disease that causes progressive changes in the nervous system. a standardised diagnostic test recommended for the global assessment of walking function by the National Multiple Sclerosis Society. The obtained results were subjected to statistical analysis.

Results: After the series of WBC treatments, a marginal but statistically significant increase in thumb strength was observed in the right hand $(\mathrm{p}<0.01)$. Other changes in the value of handgrip and thumb strength were not statistically significant. In addition, there were no statistically significant changes in the average time needed to cover the walking distance of 7.6 metres. Conclusions: The series of 20 daily WBC treatments for patients with MS did not significantly improve global walking function, although a beneficial effect on the thumb strength of the right hand was observed.

Keywords: multiple sclerosis; whole-body cryotherapy; Timed 25-Foot Walk; Hand Grip Strength Test.

potrzebnego na przejście dystansu 7,6 m, zgodnie ze standardami Timed 25-Foot Walk Test - standaryzowanego testu diagnostycznego rekomendowanego do globalnej oceny funkcji chodu przez National Multiple Sclerosis Society. Uzyskane wyniki poddano analizie statycznej.

Wyniki: Po serii zabiegów WBC odnotowano istotny wzrost siły zacisku kciuka wyłącznie po stronie prawej $(p<0,01)$. Pozostałe zmiany wartości siły zacisku ręki i kciuka nie były istotne statystycznie. Ponadto nie wykazano istotnych statystycznie zmian średnich wartości czasu niezbędnego na pokonanie dystansu 7,6 m.

Wnioski: Seria 20 codziennych zabiegów WBC nie wpływa istotnie na poprawę globalnej funkcji ruchowej chodu, choć obserwuje się korzystny wpływ jej stosowania na siłę mięśniową ręki. Słowa kluczowe: stwardnienie rozsiane; krioterapia ogólnoustrojowa; Timed 25-Foot Walk; Hand Grip Test.
These changes are associated with progressive irreversible disability in patients. One symptom of MS is mobility disorder. It is estimated that as the disease progresses, problems associated with the degenerated walking ability affect $60-90 \%$ of 
those with MS $[1,2]$. The causes of walking and balance disorders are multifactorial and have yet to be clearly described and explained. Among those known, are muscle weakness, especially in the lower limbs, loss of neuromuscular coordination, occurrence of spasticity, impaired sensory function and fatigue [3]. Among the many methods of assessing the functional status of patients with MS, the National Multiple Sclerosis Society has proposed a standardised Timed 25-Foot Walk (T25-FW) test, allowing a globalised assessment of the walking function. This test is a component of the Multiple Sclerosis Functional Composite (MSFC), which is often used in clinical trials to assess patient condition [4]. The T25-FW test is easy to carry out, does not require specialised equipment, so is often useful in assessing the walking function over the course of the disease. Importantly, T25-FW has been shown to correlate positively with several other tools used in clinical trials for walking analysis [5].

One of the basic elements affecting global motor function presented by a patient is muscle strength. About $75 \%$ of MS patients report upper limb dysfunction. These problems can be caused by a variety of factors, of which the following are mentioned most often: muscle weakness, ataxia, sensory disturbances, increased muscle tone and chronic fatigue. The abnormal functioning of the upper limbs significantly affect the ability to perform everyday activities, causing some limitation and thus affecting the quality of life of patients $[6,7,8]$. Handgrip strength is often used in a simple analysis of arm function or a general decrease in functionality. It is a necessary factor for functional independence in everyday life, closely related to dexterity and, therefore, also to general functional efficiency [9]. The Hand Grip Strength Test is a simple and quick way to assess global handgrip strength.

One of the main physical treatments used in the therapy of patients with MS is whole-body cryotherapy (WBC). The procedure can be carried out only after elimination of contraindications and qualification for it by a physician. A patient properly prepared for the treatment (equipped with an appropriate outfit, the parts of the body most exposed are protected from frostbite, instruction about behaviour during the treatment), stays in a cryochamber at a temperature of -110 to $-160^{\circ} \mathrm{C}$ for 2-3 min [10]. Whole-body cryotherapy is mainly used to relieve fatigue, inflammation and pain, both in the context of physical recovery after heavy physical exertion as well as in the course of numerous disorders (e.g. arthritis, fibromyalgia, depression) [11]. Numerous studies have also shown the positive effects of WBC in an increase in muscle strength, reduction of spasticity, increase of antioxidant activity in the body, reduction of disability among patients with neurological symptoms [12, $13,14,15,16]$. In recent years, WBC has become very popular and is now one of the main elements of comprehensive rehabilitation of patients with MS [17].

The aim of this study was to assess the effect of a series of 20 daily WBC treatments on global walking function and muscle strength in MS patients, based on assessment methods commonly available for physiotherapists and which can be used with MS patients.

\section{MATERIALS AND METHODS}

The study group consisted of 25 people ( 19 women and 6 men) diagnosed with MS. The average age of the subjects was 44.58 \pm 12.15 years. In the first stage of the study, the medical documentation provided by the volunteers and the state of health of the subjects during a detailed medical examination (including neurology) were verified. The inclusion criteria were as follows:

- documented diagnosis of MS,

- functional status classified according to the Expanded Disability Status Scale (EDSS) of 6 or below [18],

- no contraindications found in the medical examination for a series of WBC treatments.

None of the patients showed increased muscle tone in the upper limbs according to the Modified Ashworth Scale [19]. In each of the subjects qualified for the tests the global handgrip and thumb grip strength was measures using a Saehan hydraulic hand dynamometer (Hand Grip Strength Test) and a T25-FW test was carried out, measuring the time needed for the fastest but safe walk over a distance of 7.6 metres ( 25 feet). According to the required standards, the test and measurements were carried out 2, one after the other [20].

The participants then underwent a series of $20 \mathrm{WBC}$ treatments; the duration of the treatment was in the range of $2-3$ min, and the temperature in the treatment chamber was $-110^{\circ} \mathrm{C}$. Treatments were performed each weekday over 4 consecutive weeks. Each time after the treatment, the subjects underwent $30 \mathrm{~min}$ of individual physical rehabilitation.

Between day 2 and day 4, after the end of a series of WBC treatments, the measurement of the global handgrip and thumb grip strength and the time of walking a distance of 7.6 metres was repeated.

The tests were carried out at the Central Clinical Hospital of the Ministry of Internal Affairs and Administration in Warsaw, at the Centre for Therapeutic Rehabilitation. The study was approved by the Bioethics Committee of the Pomeranian Medical University in Szczecin (PMU); Approval No.: KB-0012/34/15. The study was carried out as part of the statutory activity of the Department of Functional Diagnostics and Physical Medicine of the PMU and the research projects for young scientists implemented in the years 2014-2017, being financed by a grant from the Ministry of Science and Higher Education obtained by the PMU Faculty of Health Sciences (WNoZ-318-01/S/13; MB-318-06/15, MB-318-149/15; MB-318-08/15). Each of the subjects included in the study was informed in detail about the test procedures and had given their written consent in accordance with the Helsinki Declaration.

The obtained results were subjected to statistical analysis using the Statistica v12.5 PL computer software package. In addition to descriptive statistics (arithmetic mean, standard deviation), the normality of the distribution of tested parameters was determined using a Shapiro-Wilk test. For values showing an abnormal distribution, a non-parametric Wilcoxon test was used. However, for values showing a normal distribution, a "paired Student's t-test" was used. For the above-mentioned statistical analyses, a significance level of $\mathrm{p}<0.05$ was adopted. 


\section{RESULTS}

Mean values for handgrip and thumb grip strength on a hydraulic dynamometer, measured before and after the series of WBC treatments, are presented in Table 1 . The statistical analysis only showed a significant increase in strength with respect to the right hand thumb grip strength $(\mathrm{p}<0.01)$. Other changes in the values of the right hand and left hand grip strengths did not show statistical significance.

TABLE 1. Statistical analysis of the change of handgrip and thumb strength on a hydraulic dynamometer following a series of whole-body cryotherapy treatments

\begin{tabular}{cccc}
\multicolumn{2}{c}{$\mathbf{n}=\mathbf{2 5}$} & $\mathrm{T}_{0}$ & $\mathrm{~T}_{1}$ \\
\hline \multirow{2}{*}{ HGS } & right $(\mathrm{kg})$ & $32.15 \pm 9.60$ & $31.85 \pm 9.68$ \\
\cline { 2 - 4 } & left $(\mathrm{kg})$ & $28.69 \pm 10.76$ & $27.36 \pm 10.20$ \\
\hline \multirow{2}{*}{ TS } & right $(\mathrm{kg})$ & $7.68 \pm 2.07$ & $7.98 \pm 2.25^{\star *} \mathrm{~T}_{0}$ \\
\cline { 2 - 4 } & left $(\mathrm{kg})$ & $7.33 \pm 1.86$ & $6.89 \pm 1.71$ \\
\hline
\end{tabular}

HGS - hand grip strength; TS - thumb strength; $T_{0}$ - before WBC; $T_{1}$ - after WBC

Mean values for the timed 25 foot walking distance $(7.6$ metres) in 2 independent trials in the studied MS patients are listed in Table 2. Statistical analysis did not show any significant change in the time needed to cover a distance of 7.6 metres following a series of WBC treatments used in both the 1st and 2nd trial.

TABLE 2. Measured times for the Timed 25 -Foot Walk test following wholebody cryotherapy treatments

\begin{tabular}{ccccc}
$\mathbf{n = 2 5}$ & \multicolumn{2}{c}{$\mathrm{T}_{\mathbf{0}}-\mathbf{2 5}$ foot walk } & \multicolumn{2}{c}{$\mathrm{T}_{1}-\mathbf{2 5}$ foot walk } \\
\hline trial 1 $(\mathrm{s})$ & trial 2 $(\mathrm{s})$ & trial 1 $(\mathrm{s})$ & trial 2 (s) \\
\hline $5.69 \pm 2.31$ & $5.19 \pm 1.66$ & $5.51 \pm 1.91$ & $5.20 \pm 1.66$ \\
\hline
\end{tabular}

$\mathrm{T}_{0}$ - before WBC; $\mathrm{T}_{1}$ - after WBC

\section{DISCUSSION}

In recent years, WBC has become a physical treatment increasingly used in rehabilitation [21]. There are a number of studies that demonstrate the benefits of its use in the course of various diseases, including patients with MS. Studies describing the positive effect of WBC on MS patients focus, among others, on changes in the physicochemical parameters of the blood, or reductions in oxidative stress $[12,13,14,15,16]$. When analysing available literature, a number of studies can be found that indicate the beneficial effects of frequent WBC in biological renewal - improving muscle strength, faster muscle recovery after exercise, improved cardiovascular and hormonal systems, better lipid changes in the body, and many others factors showing an improved functional status of the body [22, 23, 24, 25].

The described impact of WBC has a positive effect not only on the physical sphere but also has a proven positive effect on the human psyche. This is indicated by the findings of many authors who analysed the effect of WBC on the levels of depression, fatigue, general well-being and thus also improvements in the quality of life $[26,27]$, also in the case of patients with MS [11]. To our knowledge, there are a small number of studies assessing the effect of WBC on the functional status of MS patients in terms of their physical fitness. Our study did not show any significant effect from the series of 20 WBC treatments on improving the walking function among people with MS, as measured by the T25-FW test. It should however be emphasised that the T25-FW test, although easy to perform, is characterised by a low sensitivity as it requires at least a $20 \%$ change in the walking pace in order to be considered clinically significant, which would have a significant effect on the results obtained [6]. Miller et al. [11] received different results in this regard when analysing the functional status of patients with MS when using the much more extensive Rivermead Motor Assessment (RMA) test, which includes global assessment of motor activity, assessment of lower limb and torso functions and assessment of upper limb functions. The Miller study showed the positive effect of 10 WBC sessions in all 3 RMA test sections in patients with MS diagnosed with fatigue syndrome [11]. The RMA test used in the cited study analyses the patient's motor functions in more detail. It does not include an analysis of the time to cover a given distance, but focuses on performing particular tasks related to moving. In other studies, Miller analysed the effect of WBC on the degree of disability using the EDSS, and the strength of selected lower limb muscles using the Lovett test. These methods also do not assess the pace of walking, but indirectly analyse the functionality associated with independent movement. The results of that study were cited to have shown the significant effect of cryotherapy on the assessed parameters in patients with MS without diagnosed fatigue syndrome [28].

Hand function is undoubtedly an important factor that affects the daily functioning of every human being. Among patients with MS, there is a decrease in upper limb and hand function in approximately $3 / 4$ of cases, thus limiting their independence and reducing their quality of life [29]. To our knowledge, there are no studies on the effect of WBC on changes in the strength of hand grip and thumb grip in patients with MS. Our study was conducted among a group of 25 people with MS and showed no significant changes in this respect, with the exception of a marginal but statistically significant increase in the strength of the thumb grip in the right hand. A marginal decrease in hand grip strength and in the left hand thumb grip was observed following the series of WBC treatments which were not statistically significant, so perhaps this tendency was coincidental and not related to the WBC treatments. To confirm these results, the analysis should be extended to a larger group of subjects. The effect of a cold stimulus among 30 healthy volunteers on their grip strength was studies by a group of scientists from Brazil. They showed a significant decrease in this parameter after a 15-minute immersion of the elbow in water at $-10^{\circ} \mathrm{C}$. The reduction in grip strength continued up to 30 min after the cold stimulus ended, after which it had returned to normal [30]. In the cited study, however, a much 
warmer stimulus temperature was used and in a more heat conductive medium than in the case of the WBC treatments, therefore it cannot be concluded that similar results would be obtained after using temperatures lower than $-110^{\circ} \mathrm{C}$. It is also difficult to assess whether similar effects would be obtained in a group of people with MS.

\section{CONCLUSIONS}

1. The series of 20 whole-body cryostimulation treatments did little to increase muscle strength as assessed by the Hand Grip Strength Test.

2. The series of WBC treatments did not significantly improve global motor function for walking, but does not cause any deterioration.

3. The T25-FW test, due to its low sensitivity, seems to be an inappropriate tool for assessing the effect of whole-body cryostimulation on changes in the walking rate of patients with MS.

\section{REFERENCES}

1. Sutliff MH. Contribution of impaired mobility to patient burden in multiple sclerosis. Curr Med Res Opin 2010;26(1):109-19.

2. Mickiewicz P, Garczyński W. Możliwości funkcjonalne chorych na stwardnienie rozsiane w zależności od czasu trwania choroby. J Education Health Sport 2016;6(9):757-71.

3. Panitch H, Applebee A. Treatment of walking impairment in multiple sclerosis: an unmet need for a disease-specific disability. Expert Opin Pharmacother 2011;12(10):1511-21.

4. Polman CH, Rudick RA. The multiple sclerosis functional composite: a clinically meaningful measure of disability. Neurology 2010;74 Suppl 3:S8-15.

5. Ontaneda D, LaRocca N, Coetzee T, Rudick R. Revisiting the multiple sclerosis functional composite: proceedings from the National Multiple Sclerosis Society (NMSS) Task Force on Clinical Disability Measures. Mult Scler 2012;18(8):1074-80.

6. Goodman AD, Brown TR, Cohen JA, Krupp LB, Schapiro R, Schwid SR, et al. Dose comparison trial of sustained-release fampridine in multiple sclerosis. Neurology 2008;71(15):1134-41.

7. Johansson S, Ytterberg C, Claesson IM, Lindberg J, Hillert J, Andersson M, et al. High concurrent presence of disability in multiple sclerosis. Associations with perceived health. J Neurol 2007;254(6):767-73.

8. Kierkegaard M, Einarsson U, Gottberg K, von Koch L, Holmqvist LW. The relationship between walking, manual dexterity, cognition and activity/participation in persons with multiple sclerosis. Mult Scler 2012;18(5):639-46.

9. Severijns D, Lamers I, Kerkhofs L, Feys P. Hand grip fatigability in persons with multiple sclerosis according to hand dominance and disease progression. J Rehabil Med 2015;47(2):154-60.

10. Lubkowska A. Zastosowanie krioterapii w chorobach przewlekłych. Fam Med Primary Care Rev 2013;15(2):233-9.
11. Miller E, Kostka J, Włodarczyk T, Dugué B. Whole-body cryostimulation (cryotherapy) provides benefits for fatigue and functional status in multiple sclerosis patients. A case-control study. Acta Neurol Scand 2016;134(6):420-6. doi: 10.1111/ane.12557.

12. Miller E, Mrowicka M, Malinowska K, Mrowicki J, Saluk-Juszczak J, Kędziora J. The effects of whole-body cryotherapy on oxidative stress in multiple sclerosis patients. J Therm Biol Psychiatry 2010;35(8):406-10.

13. Miller E, Mrowicka M, Malinowska K, Żołyński K, Kędziora J. Effects of whole-body cryotherapy on total antioxidative status and activities of some antioxidative enzymes in blood of patients with multiple sclerosis - preliminary study. J Med Invest 2010;57(1-2):168-73.

14. Miller E, Markiewicz Ł, Saluk J, Majsterek I. Effects of short-term cryostimulation on antioxidative status and its clinical applications in humans. Eur J Appl Physiol 2012;112(5):1645-52.

15. Miller E, Mrowicka M, Malinowska K, Mrowicki J, Saluk-Juszczak J, Kędziora J. Effects of whole body cryotherapy on a total antioxidative status and activities of antioxidant enzy mes in blood of depressive multiple sclerosis patients. World J Biol Psychiatry 2011;12(3):223-7.

16. Miller E, Saluk J, Morel A, Wachowicz B. Long-term effects of whole body cryostimulation on uric acid concentration in plasma of secondary progressive multiple sclerosis patients. Scand J Clin Lab Invest 2013;73(8):635-40.

17. Zwolińska J, Kwolek A, Gąsior M. Skuteczność czynników fizykalnych wykorzystywanych w leczeniu osób ze stwardnieniem rozsianym. Przegląd piśmiennictwa. Post Rehab 2015;29(3):35-42.

18. Kurtzke JF. Rating neurologic impairment in multiple sclerosis: an expanded disability status scale (EDSS). Neurology 1983;33(11):1444-52.

19. Bohannon RW, Smith MB. Interrater reliability of a modified Ashworth scale of muscle spasticity. Phys Ther 1987;67(2):206-7.

20. Cohen JA, Krishnan AV, Goodman AD, Potts J, Wang P, Havrdova E, et al. The clinical meaning of walking speed as measured by the timed 25-foot walk in patients with multiple sclerosis. JAMA Neurol 2014;71(11):138693. doi: 10.1001/jamaneurol.2014.1895.

21. Rymaszewska J, Pawik M. Czy krioterapia ogólnoustrojowa staje się formą terapii? Fam Med Primary Care Rev 2013;15(2):247-50.

22. Lubkowska A, Banfi G, Dołęgowska B, d’Eril GV, Łuczak J, Barassi A. Changes in lipid profile in response to three different protocols of whole-body cryostimulation treatments. Cryobiology 2010;61(1):22-6.

23. Lubkowska A, Szyguła Z, Klimek AJ, Torii M. Do sessions of cryostimulation have influence on white blood cell count, level of IL6 and total oxidative and antioxidative status in healthy men? Eur J Appl Physiol 2010;109(1):67-72.

24. Jonak A, Skrzek A. Krioterapia w odnowie biologicznej sportowców przegląd badań. Acta Bio-Opt Inform Med 2009;15(4):319-21.

25. Stanek A, Sieroń A. Współczesna krioterapia ogólnoustrojowa w odnowie biologicznej. Ann Acad Med Siles 2012;66(4):64-70.

26. Rymaszewska J, Ramsey D, Chładzińska-Kiejna S, Kiejna A. Czy krótkotrwała ekspozycja na skrajnie niskie temperatury może być pomocna w leczeniu zaburzeń depresyjnych i lękowych? Psychiatr Pol 2007;41(5):625-36.

27. Szczepańska-Gieracha J, Borsuk P, Pawik M, Rymaszewska J. Mental state and quality of life after 10 session whole body cryotherapy. Psychol Health Med 2014;19(1):40-6.

28. Miller E. Kriostymulacja czynnikiem wspomagającym rehabilitację chorych na stwardnienie rozsiane z zespołem zmęczenia. Wiad Lek 2010;63(2):41-5.

29. Lamers I, Feys P. Upper limb function in patients with multiple sclerosis. Annals Physical Rehabilitation Med 2013;56(1):358-9.

30. Reis Rabelo PH, Pereira Botelho KK, Barbosa de Oliveira F. Grip strength after forearm cooling in healthy subjects. Fisioter Mov 2016;29(4):685-92. 